\title{
Transformation of phosphorus species in settling seston and during early sediment diagenesis
}

\author{
M. Hupfer ${ }^{1 *}$, R. Gächter ${ }^{1}$ and R. Giovanoli ${ }^{2}$ \\ 1 Swiss Federal Institute for Environmental Science and Technology (EAWAG), Limnological \\ Research Center, CH-6047 Kastanienbaum, Switzerland \\ 2. Laboratory for Electron Microscopy, University of Bern, CH-3000 Bern 9, Freiestrasse 3, \\ Switzerland
}

Key words: Phosphorus fractionation, EDXS, sediment diagenesis, phosphorus release, settling seston, Metallogenium.

\begin{abstract}
Sequential $\mathrm{P}$ extraction was combined with electron microscop and $\mathrm{X}$-ray spectroscopy to characterise various $P$ species and to study their transformation in settling seston and in recent sediment. During early diagenesis most of the particulate $P$ formed in the water was redissolved. No net transformation into species that would resist dissolution was observed.

It was shown that

- the phosphorus (P) content and the P flux of settling particles varied seasonally over one order of magnitude

- particles became enriched with reductant soluble $\mathrm{P}$ (BD-P) while settling through the hypolimnion

- changes in BD-P were highly significantly correlated with changes in reductant soluble iron (BD-Fe)

- bacteria oxidising Fe and Mn seemed to be mainly responsible for this increase in P concentration

- other fractions including organic $P$ did not change during sedimentation

- most of the organic $P$ and of the Fe bound P and $70 \%$ of TP was released from the sediment during early diagenesis

- the sediment surface did not act as a trap for P migrating upwards from deeper sediment layers

- $\mathrm{CaCO}_{3}$ sedimentation contributed little to $\mathrm{P}$ sedimentation but significantly to the permanent burial of $P$.
\end{abstract}

\section{Introduction}

Although the history of lakes is recorded in their sediments, it is not easy to read and correctly interpret these records. What does this mean? In some sediments the

\footnotetext{
* present address:

Department of Inland Water Research Magdeburg. Center of Environmental Research LeipzigHalle, Am Biederitzer Busch 12, D-39114 Magdeburg, Germany
} 
high $\mathrm{P}$ concentration in the surface layer can be attributed to increasing $\mathrm{P}$ sedimentation caused by recent eutrophication (e.g. Jorgensen et al., 1975; Kamp-Nielsen, 1974), in other lakes it could be explained by upward migration of dissolved $\mathrm{P}$ from deeper sediment layers with subsequent scavening at the sediment surface (e.g., Kemp et al., 1974; Carignan and Flett, 1981) or by diagenetic transformatior after sedimentation that leads to a loss of $\mathrm{P}$ by mineralisation or dissolution processes (Tessenow, 1975). Generally, the vertical $P$ distribution in sediment profiles is the net result of the history of $P$ sedimentation as well as of many transformation processes, such as biological uptake, adsorption, desorption, release, diffusion, precipitation, mineralisation, etc. The rate of the final burial of $P$ in the sediment (net sedimentation) depends on the chemical composition, the deposition rate of the settling seston, and on the biogeochemical transformations mentioned. Whereas some information exists about extent and seasonal variation of $\mathrm{P}$ deposition rates, only few studies have characterised $P$ species in the settling seston (Liebezeit, 1991) and related them to the resulting sediment (Ulén, 1978; Forsgren and Jansson, 1993).

Sequential extraction of $P$ as suggested by, for example, Williams et al. (1971), Hieltjes and Lijklema (1980), Golterman (1982), Psenner et al. (1984, 1988) and Ruttenberg (1992) is a useful tool for characterisation of various $\mathrm{P}$ compounds. We combined this technique with electron microscopy and X-ray spectroscopy to characterise various $P$ species and to study net-transformation among $P$ compounds in settling seston and during early sediment diagenesis.

\section{Sampling site, materials and methods}

Eutrophic, pre-alpine Lake Sempach is situated in Central Switzerland. Morphometric and limnological characteristics of this lake are summarised in Table 1.

From the 1950's to 1970's, excessive nutrient inputs originating from farmland and waste wateled to a rapid eutrophication. As a result, $\mathrm{O}_{2}$ became depleted in the hypolimnion during summer stagnation; and during winter periods mixing was not intensive enough to completely restore $\mathrm{O}_{2}$ saturation. Since 1984 pure oxygen is introduced into the hypolimnion at a rate of $3 \mathrm{t} /$ day during summer stagnation. $\mathrm{Be}-$ tween autumn and spring, the lake is aerated with $370 \mathrm{~m}^{3} / \mathrm{h}$ of pressurised air in

Table 1. Morphometric data and characteristics of Lake Sempach, Switzerland $\left(47^{\circ} 9^{\prime} N / 8^{\circ} 9^{\prime}\right.$ E)

\begin{tabular}{lc}
\hline Parameter & \\
\hline Surface area $\left(\mathrm{km}^{2}\right)$ & 14.4 \\
Mean depth $(\mathrm{m})$ & 46 \\
Maximum depth $(\mathrm{m})$ & 87 \\
Volume $\left(10^{6} \mathrm{~m}^{3}\right)$ & 639 \\
Mean residence time (years) & 17 \\
Drainage area $\left(\mathrm{km}^{2}\right)$ & 61.4 \\
Total P $\left(\mathrm{mg} / \mathrm{m}^{3}\right)$ overturn $1992 / 1993$ & 90 \\
Min. transparency $(\mathrm{m})$ & 1.5 \\
Max. transparency $(\mathrm{m})$ & 4.8 \\
\hline
\end{tabular}


order to intensify mixing and, hence, enhance $\mathrm{O}_{2}$ uptake from the atmosphere. Oxygen concentration in the water column now always exceeds $4 \mathrm{mg} / \mathrm{l}$ (Stadelmann, 1988). However, surprisingly, the release of $P$ from sediments has not decreased (Gächter, 1987; Gächter and Meyer, 1990).

Four replicates of sediment traps (diameter $9 \mathrm{~cm}$, height $70 \mathrm{~cm}$ ) were exposed at depths of $20 \mathrm{~m}$ and $80 \mathrm{~m}$ and settling particles were collected at two-week intervals. Settled material removed from the traps was kept in a cool box until further treatment within 4 hours after sampling. The material in two of the replicates was freezedried and analysed for total P (TP), POC, PON, Fe, Mn and Ca. For sampling and preparation of trap material see also Gächter and Meyer (1990). The remaining material was centrifuged at $4000 \mathrm{~g}$ for 10 minutes at $4{ }^{\circ} \mathrm{C}$ and was used for sequential $P$ extraction.

Sediment cores ( $5.5 \mathrm{~cm}$ diameter) were collected at depths of $20 \mathrm{~m}, 40 \mathrm{~m}$ and $87 \mathrm{~m}$ in June and July 1992 . The cores were kept at about $4{ }^{\circ} \mathrm{C}$ and sliced in $0.5-$ to $2 \mathrm{~cm}$ thick layers in a glove box under $\mathrm{N}_{2}$ atmosphere. To obtain a representative sample for the sampled site, the layers of five repicate cores were mixed, weighed and homogenised. Then, $25 \mathrm{ml}$ of the first extractant ( $1 \mathrm{M}$ deoxygenated $\mathrm{NH}_{4} \mathrm{Cl}$ solution) was added to $1 \mathrm{~g}$ of subsample still under $\mathrm{N}_{2}$ atmosphere. The remaining material from the sediment cores was dried at $80^{\circ} \mathrm{C}$ and was used for further analyses of total $\mathrm{P}$, organic matter (OM), Fe, Mn and Ca (see Gächter and Meyer, 1990).

In order to characterise various P-species in solid material, a sequential extraction scheme according to Psenner et al. (1984) was used with the following modifications. All extractions were conducted at room temperature. Extraction with $\mathrm{H}_{2} \mathrm{O}$ was replaced by extraction with $1 \mathrm{M} \mathrm{NH}_{4} \mathrm{Cl}$. The last extraction with hot $\mathrm{NaOH}$ was omitted. Instead, the $\mathrm{P}$ content of solid material remaining after extraction with $\mathrm{HCl}$ was determined after persulfate $\left(\mathrm{K}_{2} \mathrm{~S}_{2} \mathrm{O}_{8}\right)$ digestion. In each fraction, soluble reactive $P(S R P)$ and total $P(T P)$ were determined after filtration through a prerinsed $0.45 \mu \mathrm{m}$ membrane filter (Schleicher and Schuell, FP 030/2) according to Vogler (1965). TP of solid sediment and extracts was determined after digestion with $\mathrm{K}_{2} \mathrm{~S}_{2} \mathrm{O}_{8}$ at $120^{\circ} \mathrm{C}$ for 2 hours (Gächter et al., 1992). Concentrations of nonreactive $\mathrm{P}$ (NRP) were calculated as the difference between TP and SRP. Table 2 summarises the sequential extraction procedure and characterises the expected $P$ species in each fraction.

Concentrations of $\mathrm{Ca}, \mathrm{Fe}$ and $\mathrm{Mn}$ in sediment extracts were measured with an atomic absorption spectrometer (PERKIN ELMER 2100) operating in the flame mode. Total metal concentrations of dried sediments were determined after digesting $50 \mathrm{mg}$ of dried sediment with $2 \mathrm{ml}$ concentrated $\mathrm{HNO}_{3}$ and $0.5 \mathrm{ml} \mathrm{H}_{2} \mathrm{O}_{2}$ in a microwave digestion unit (MLS-1200) at a pressure of 30 bar.

To determine POC and total nitrogen, $50 \mathrm{mg}$ of dried material were suspended in $25 \mathrm{ml}$ of $0.5 \mathrm{M} \mathrm{HCl}$ to remove the carbonate carbon. Then, $5 \mathrm{ml}$ of the sonicated suspension were filtered through a Whatman GF/F glass-fibre filter (precombusted at $500^{\circ} \mathrm{C}$ for two hours to remove organic carbon). After drying at room temperature, the filters were analysed in a HERAEUS-CHN Analyser (CHN Rapid). Content of organic matter (OM) was determined as loss of weight after combustion . of original sediment at $450^{\circ} \mathrm{C}$ for 3 hours.

For inspection in the electron microscope, subsamples of fresh sediments were diluted with distilled water and dispersed in an ultrasonic bath. A small drop of this 
Table 2. Sequence of the modified P-extraction scheme according to Psenner et al. (1984) and the expected $P$-species in the fractions (adapted from several authors) (NR-non reactive phosphorus, SRP-soluble reactive phosphorus, TP-total phosphorus)

\begin{tabular}{|c|c|c|c|}
\hline Extractant & Time & & Expected P-forms \\
\hline 1. $\mathrm{NH}_{4} \mathrm{Cl}(1 \mathrm{M})$ & $0.5 \mathrm{~h}$ & SRP/NRP & $\begin{array}{l}P \text { in the interstitial water loosely adsorbed } \\
\left.\text { to surface (e.g. surfaces of } \mathrm{Fe} \text { and } \mathrm{CaCO}_{3}\right) \text {, } \\
\text { immediately available } P\end{array}$ \\
\hline \multirow{2}{*}{$\begin{array}{l}\text { 2. } \mathrm{BD}(0.11 \mathrm{M}) \\
\text { bicarbonate/ } \\
\text { dithionite }\end{array}$} & \multirow[t]{2}{*}{$1 \mathrm{~h}$} & SRP & $\begin{array}{l}\text { redox-sensitive } \mathrm{P} \text { mainly bound } \\
\text { to Fe-hydroxides and } \mathrm{Mn} \text {-compounds }\end{array}$ \\
\hline & & NRP & organic $\mathbf{P}$ \\
\hline \multirow[t]{2}{*}{ 3. $\mathrm{NaOH}(1 \mathrm{M})$} & \multirow[t]{2}{*}{$16 \mathrm{~h}$} & SRP & $\begin{array}{l}\mathrm{P} \text { bound to metal oxides mainly of } \mathrm{Al} \text { and } \mathrm{Fe} \text {, } \\
\text { which is exchangeable against } \mathrm{OH}^{-} \text {ions; } \\
\text { inorganic } \mathrm{P} \text { compounds soluble in bases }\end{array}$ \\
\hline & & NRP & $\begin{array}{l}\mathrm{P} \text { in microorganisms including poly- } \mathrm{P} \\
\text { organic } \mathrm{P} \text { in detritus, } \mathrm{P} \text { bound in humic } \\
\text { compounds }\end{array}$ \\
\hline \multirow[t]{2}{*}{ 4. $\mathrm{HCl}(0.5 \mathrm{M})$} & \multirow[t]{2}{*}{$16 \mathrm{~h}$} & SRP & $\begin{array}{l}\text { P bound to carbonates and apatite-P, } \\
\text { traces of hydrolysed organic } P\end{array}$ \\
\hline & & NRP & organic P \\
\hline 5. Residual-P & & TP & organic and other refractory $\mathbf{P}$ \\
\hline
\end{tabular}

suspension was deposited on a bronze grid coated with carbon film. After air drying, the morphological structures were examined with a HITACHI H600-2 electron microscope using both conventional and scanning transmission techniques. Qualitative element analysis of whole sediment particles and microanalysis were carried out with an energy dispersive X-ray spectroscopy system (NORAN TN-5402). Element mapping was performed with an MSCAN2 program showing the localisation of $P$ and of other elements.

Furthermore, selected freeze-dried samples were analysed by SEM (JOEL ISM840 ) equipped with energy dispersive $X$-ray spectrometer. The installed SQ-program allows quantitative element analysis and, hence, the estimation of element ratios.

\section{Results}

Seasonal aspects of $P$ sedimentation

Sedimentation rates exhibited a distinct seasonal pattern, with high rates during summer stratification and lower rates during partial and complete overturn. During summer months autochthonous $\mathrm{CaCO}_{3}$ contributed to up to $88 \%$ of the total sedimentation. The annual average portion of $\mathrm{CaCO}_{3}$ and of organic matter amounted to $54 \%$ and $16 \%$, respectively $(1988-1993)$. TP concentration of the settling material varied over one order of magnitude (between 1 and more than $10 \mathrm{mg} / \mathrm{g} \mathrm{DW}$ ) 

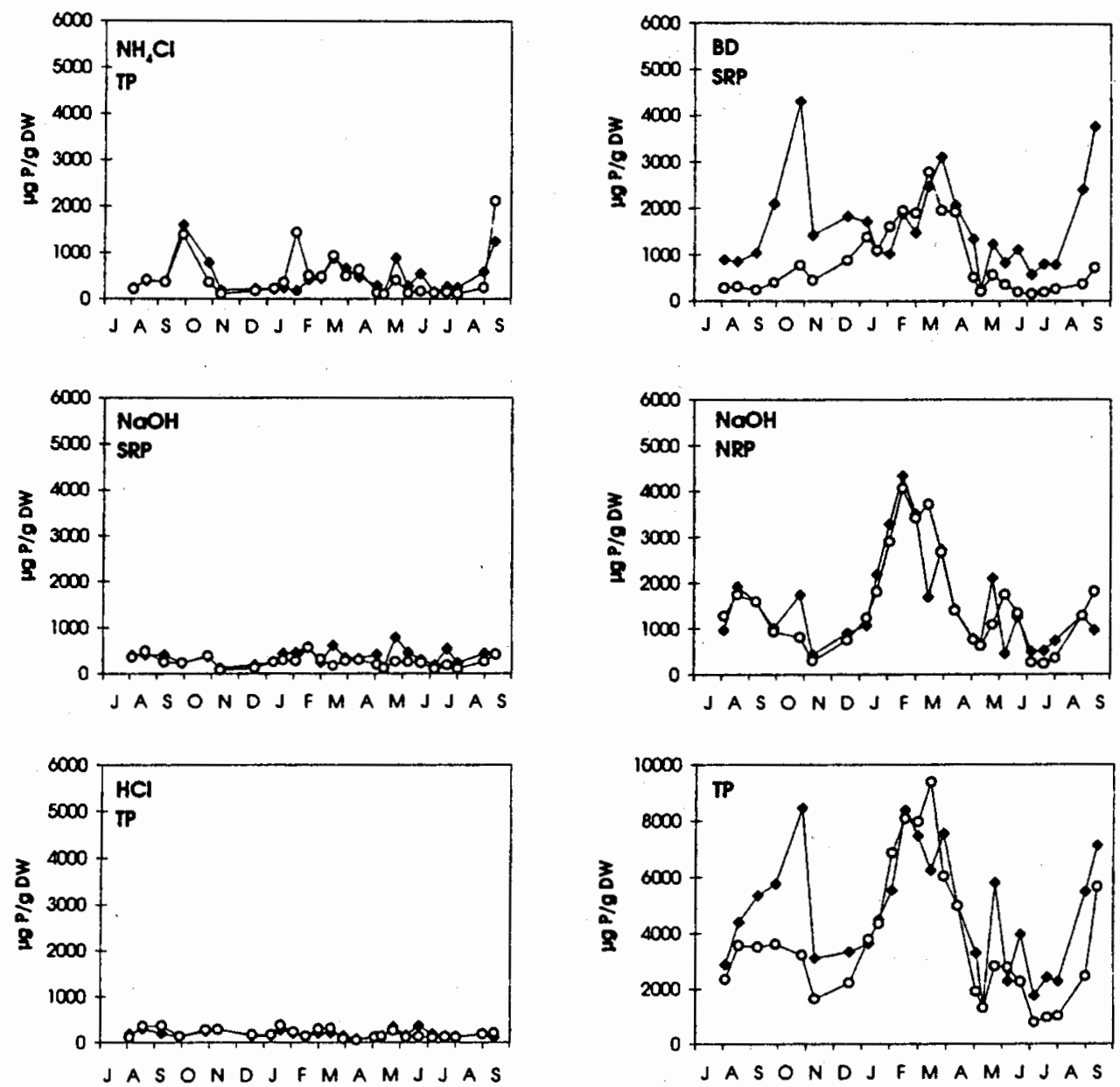

Figure 1. Seasonal variations of $P$ fractions and total phosphorus (TP) in the settling material

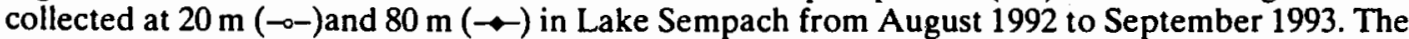
shaded area marks the period of winter overturn. Note that the scale for TP differs from that of the other $\mathbf{P}$ fraction

depending on season and sampling depth (Fig. 1). In settling particles collected at $20 \mathrm{~m}$, concentrations were highest at the end of spring overturn and lowest from May to August. During overturn, TP concentrations of material collected at $20 \mathrm{~m}$ and $80 \mathrm{~m}$ were similar. However, during summer stagnation $P$ concentrations of the material collected at $80 \mathrm{~m}$ were distinctly higher. As shown in Figure 1 and in Table 3, $\mathrm{NH}_{4} \mathrm{Cl}-\mathrm{TP}, \mathrm{NaOH}-\mathrm{SRP}, \mathrm{HCl}-\mathrm{TP}$ and residual $\mathrm{P}$ contributed little to the seasonal variation or to the elevated TP concentrations observed at $80 \mathrm{~m}$ during summer. It is obvious from Figure 2 that even during seasons with high $\mathrm{CaCO}_{3}$ sedimentation, $\mathrm{HCl}$-TP always was of minor importance and could not account for the seasonal variations of the TP fluxes. This is partly due to the fact that during the season of high autochthonous $\mathrm{CaCO}_{3}$ precipitation (April to August) the average $\mathrm{HCl}-\mathrm{P}$ : Ca ratio $(0.4 \mathrm{mg} \mathrm{P} / \mathrm{g} \mathrm{Ca}$ ) was five times lower than during the period of low $\mathrm{CaCO}_{3}$ precipitation (September to March). The $\mathrm{NaOH}-\mathrm{NRP}$ flux was related to 
Table 3. Fractional P-composition (in \% of total P) and average flux rates $\left(\mathrm{mg} \mathrm{P} / \mathrm{m}^{2} \mathrm{~d}\right.$ ) of different P-forms of the settled material collected at 20 and $80 \mathrm{~m}$ in Lake Sempach (Aug. 1992-Sept. 1993), during stratification and turnover periods. BD-NRP (about $5 \%$ of TP) was not considered in these calculations

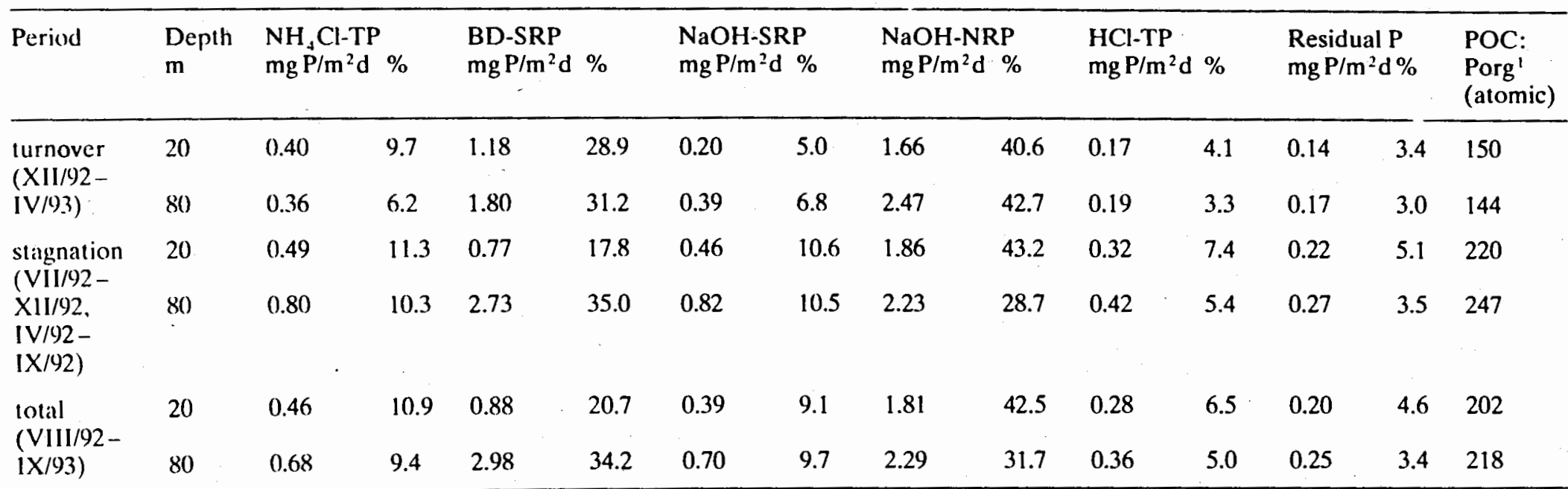

- Porg $=\mathrm{NaOH}-\mathrm{NRP}$ 

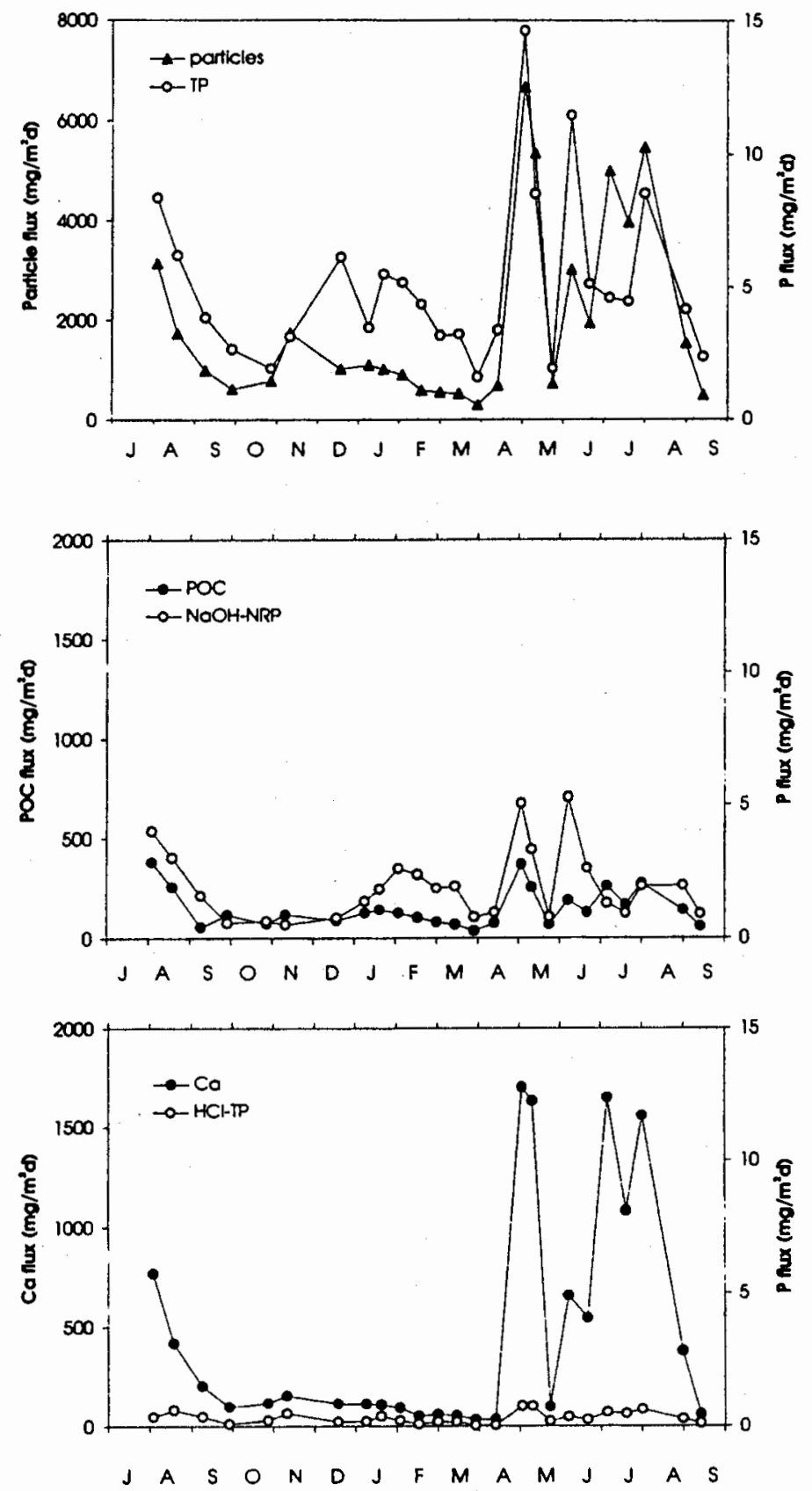

Figure 2. Seasonal variations of POC. Ca, NaOH-NRP. HCl-TP and TP fluxes at $20 \mathrm{~m}$ in Lake Sempach from August 1992 to September 1993. The shaded area marks the period of winter overturn 
A

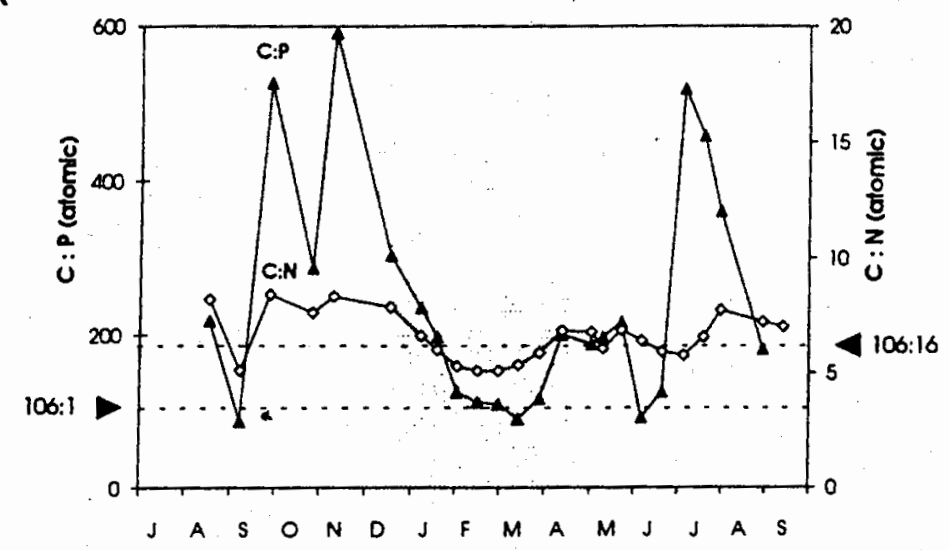

B

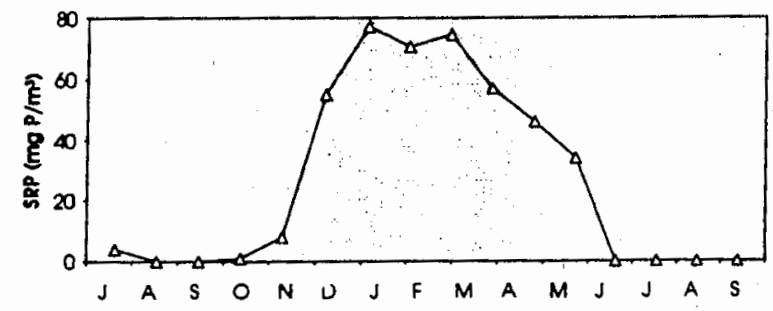

Figure 3. A: Seasonal variations of POC: $\mathrm{NaOH}-\mathrm{NRP}$ and POC:PN ratios of material collected with a sediment trap at the $20 \mathrm{~m}$ depth in Lake Sembach. The dotted lines represent the Redfield ratios. The shaded area marks the period of winter overturn. B: Seasonal variation of the SRP concentration observed at $10 \mathrm{~m}$ in Lake Sempach from August 1992 to September 1993. The shaded area marks ther period of winter overturn

the flux of POC and always clearly exceeded the flux of HCl-TP. NaOH-NRP was the dominant fraction during most seasons at $20 \mathrm{~m}$ and during turnover in $80 \mathrm{~m}$. Only at the end of spring overturn BD-SRP and $\mathrm{NaOH}-\mathrm{NRP}$ were about equally important and in late summer the latter fraction contributed most to the total $P$ in the $80 \mathrm{~m}$-samples. Although during turnover the average POC flux $\left(96 \mathrm{mg} \mathrm{m}^{-2} \mathrm{~d}^{-1}\right)$ was distinctly lower than during stagnation $\left(159 \mathrm{mg} \mathrm{m}^{-2} \mathrm{~d}^{-1}\right)$, the organic $P$ flux ( $\mathrm{NaOH}-\mathrm{NRP}$ ) attained similar average rates during both periods (stagnation: $1.86 \mathrm{mg}^{-2} \mathrm{~d}^{-1}$, turnover: $1.66 \mathrm{mg} \mathrm{m}^{-2} \mathrm{~d}^{-1}$; see Table 3 ). This is a consequence of the seasonally variable $C_{\text {org }}: P_{\text {org }}$ ratio for particles settling in to the hypolimnion (Fig. 3 ). It was close to the Redfield ratio of 106 (Redfield et al., 19,3) during winter overturn when $P$ was not limiting; but it approached values of 500 during summer when the $\mathrm{PO}_{4}-\mathrm{P}$ in the $0-10 \mathrm{~m}$ water layer was lower than $2 \mu \mathrm{g} P / 1$. Compared to $\mathrm{C}_{\text {org }}: \mathrm{P}_{\text {org }}$ ratio the $\mathrm{C}_{\text {org }}$ : $\mathrm{N}$ ratio varied only about 2-fold between August 1992 and September 1993 but it also exhibited a clear seasonal cycle.

\section{Changes during sedimentation}

As indicated in Table 4, the total particle flux at $80 \mathrm{~m}$ exceeded the flux at $20 \mathrm{~m}$ by only $11 \%$ during the summer. However, the P. Fe and Mn fluxes increased 1.8 -fold. 
Table 4. Average flux rates $\left(\mathrm{mg} / \mathrm{m}^{2} \mathrm{~d}\right)$ at different sampling depths during turnover and stratification in Lake Sempach. The average values of this study are compared with the average values of the last ten (1984-1993) or six years $(1988-1993)$

\begin{tabular}{|c|c|c|c|c|}
\hline \multirow[t]{2}{*}{ Parameter } & \multirow[t]{2}{*}{ Period } & \multicolumn{2}{|c|}{ Depth } & \multirow{2}{*}{$\begin{array}{l}\text { ratio } \\
80 / 20 \mathrm{~m}\end{array}$} \\
\hline & & $20 \mathrm{~m}$ & $80 \mathrm{~m}$ & \\
\hline Particle flux & $\begin{array}{l}\text { turnover } \\
\text { stagnation } \\
\text { total (VII/92-IX/93) } \\
1984-1993\end{array}$ & $\begin{array}{r}770 \\
2140 \\
1760 \\
1900\end{array}$ & $\begin{array}{l}1080 \\
2380 \\
2030 \\
2090\end{array}$ & $\begin{array}{l}1.4 \\
1.1 \\
1.2 \\
1.1\end{array}$ \\
\hline POC flux & $\begin{array}{l}\text { turnover } \\
\text { stagnation } \\
\text { total (VIII/92-IX/93) } \\
1984-1993\end{array}$ & $\begin{array}{r}96 \\
159 \\
142 \\
163\end{array}$ & $\begin{array}{l}138 \\
213 \\
193 \\
195\end{array}$ & $\begin{array}{l}1.4 \\
1.3 \\
1.4 \\
1.2\end{array}$ \\
\hline PON flux & $\begin{array}{l}\text { turnover } \\
\text { stagnation } \\
\text { total (VIII/92-IX/93) } \\
1984-1993\end{array}$ & $\begin{array}{l}19.2 \\
22.9 \\
21.9 \\
25.6\end{array}$ & $\begin{array}{l}27.6 \\
35.2 \\
33.1 \\
32.9\end{array}$ & $\begin{array}{l}1.4 \\
1.5 \\
1.5 \\
1.3\end{array}$ \\
\hline Total P flux & $\begin{array}{l}\text { turnover } \\
\text { stagnation } \\
\text { VIII/92-IX/93 } \\
1984-1993\end{array}$ & $\begin{array}{l}4.0 \\
5.0 \\
4.7 \\
5.3\end{array}$ & $\begin{array}{l}5.3 \\
9.0 \\
8.0 \\
8.1\end{array}$ & $\begin{array}{l}1.3 \\
1.8 \\
1.7 \\
1.5\end{array}$ \\
\hline Fe flux & $\begin{array}{l}\text { turnover } \\
\text { stagnation } \\
\text { total (VIII/92-IX/93) } \\
1988-1993\end{array}$ & $\begin{array}{l}15.4 \\
12.7 \\
13.4 \\
13.1\end{array}$ & $\begin{array}{l}19.8 \\
23.4 \\
22.4 \\
26.7\end{array}$ & $\begin{array}{l}1.3 \\
1.8 \\
1.7 \\
2.0\end{array}$ \\
\hline Mn flux & $\begin{array}{l}\text { turnover } \\
\text { stagnation } \\
\text { total (VIII/92-IX/93) } \\
1988-1993\end{array}$ & $\begin{array}{l}7.6 \\
1.2 \\
2.9 \\
4.1\end{array}$ & $\begin{array}{l}17.3 \\
35.6 \\
30.6 \\
32.9\end{array}$ & $\begin{array}{r}2.3 \\
29.7 \\
10.4 \\
8.0\end{array}$ \\
\hline Ca flux & $\begin{array}{l}\text { turnover } \\
\text { stagnation } \\
\text { total (VIII/92-IX/93 } \\
1988-1993\end{array}$ & $\begin{array}{r}80 \\
521 \\
401 \\
385\end{array}$ & $\begin{array}{l}108 \\
465 \\
368 \\
346\end{array}$ & $\begin{array}{l}1.3 \\
0.9 \\
0.9 \\
0.9\end{array}$ \\
\hline
\end{tabular}

1.8-fold and 30 -fold, respectively, whereas the Ca flux decreased by $10.7 \%$. In contrast, during winter overturn the $\mathrm{P}, \mathrm{Fe}, \mathrm{Mn}$, and $\mathrm{Ca}$ fluxes observed at $80 \mathrm{~m}$ exceeded the fluxes at $20 \mathrm{~m}$ approximately in proportion to the increased particle flux. These observations suggest that during summer the fluxes of $\mathrm{P}, \mathrm{Fe}$ and $\mathrm{Mn}$ were higher at $80 \mathrm{~m}$ than at $20 \mathrm{~m}$ because the setting particles became enriched in these three elements while settling through the hypolimnion. However, during winter overturn, increased flux rates of $\mathrm{Ca}, \mathrm{Fe}$ and $\mathrm{TP}$ at the depth of $80 \mathrm{~m}$ seemed to be caused mainly by the increased particle flux, likely due to increased sediment resuspension.

As shown in Figure 4 a, differences in TP concentrations observed at the two sampling depths were mainly due to the different BD-TP concentrations of the collected particles. Furthermore, as shown in Figure $4 \mathrm{~b}$, the increase in BD-TP was 

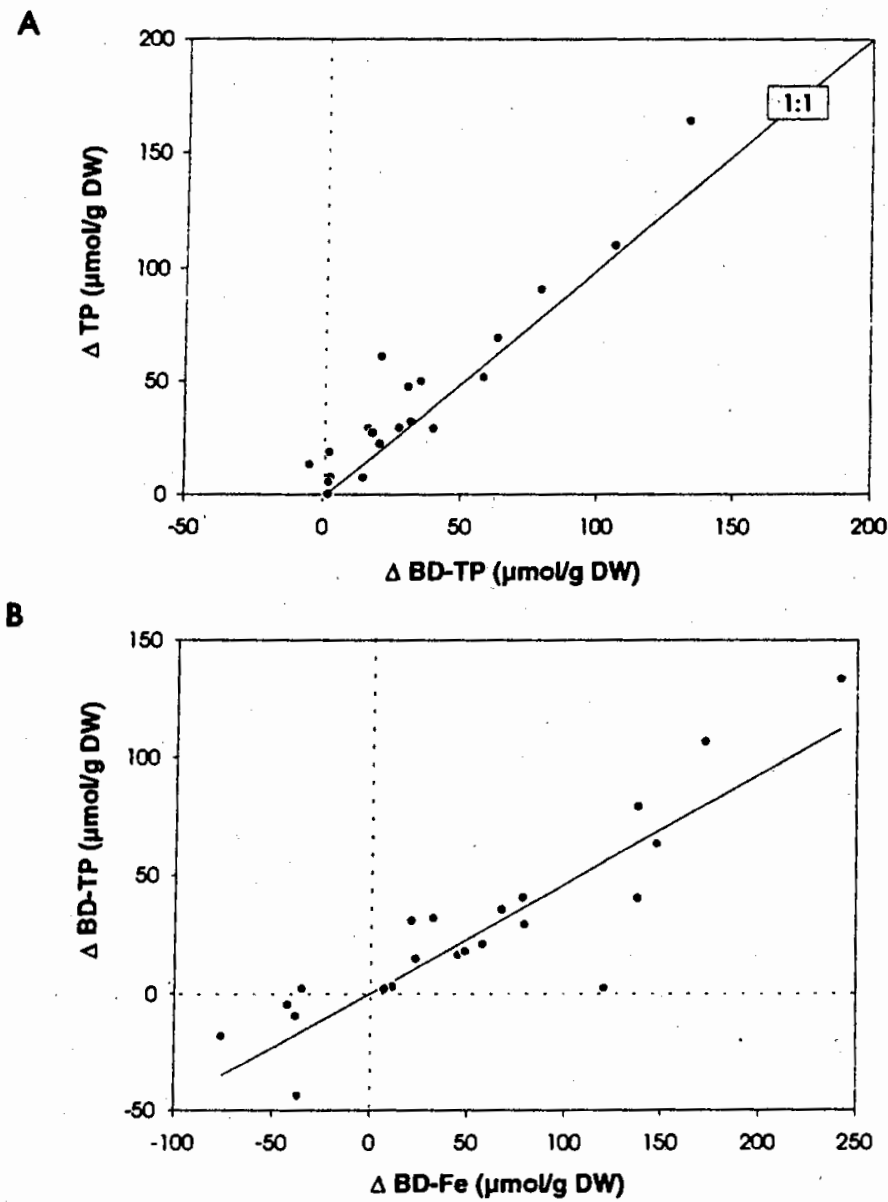

Figure 4. A: Differences in TP versus differences in BD-TP concentrations of settling particles simultaneously collected at the depths of 20 and $80 \mathrm{~m}$. The solid line represents a $1: 1$ relationship. B: Linear correlation between differences in BD-P and BD-Fe concentrations of settling particles simultaneously collected at the depths of 20 and $80 \mathrm{~m}$. (BD-TP $\left.=0.46 \mathrm{BD}-\mathrm{Fe}, \mathrm{n}=22, r^{2}=0.78\right)$

linearly related to a simultaneous increase in $\mathrm{BD}$ reducible iron, suggesting that the increase in BD-TP was due to the formation of a solid, BD-reductant soluble Fe-P complex with an average atomic $F e: P$ ratio of about 2.2. Consequently, the average ratio of $B D-F e: B D-T P$ decreased with increasing sampling depth from 3.6 at $20 \mathrm{~m}$ level to 2.7 at the $80 \mathrm{~m}$ level.

Investigations with the electron microscope support the hypothesis of a structural coupling of Fe and P. Figure 5 shows spider-like structure that were mainly observed in the $80 \mathrm{~m}$ traps. These structures are identical to manganese oxidising micro-organisms of the type Metallogenium described by Gregory et al. (1980), Giovanoli et al. (1980), Diem (1983), Miyajima (1992) and others. Element mapping of these structures indicated that $\mathrm{P}$ was best correlated with $\mathrm{Fe}$ and $\mathrm{K}$. Some but not all locations with a high density in $\mathrm{P}$ were enriched with $\mathrm{Ca}$ and $\mathrm{Mn}$. Semiquantitative microanalysis by means of STEM with X-ray spectroscopy confirmed that Metallogenium structures enriched in $\mathrm{P}$ simultaneously contained high $\mathrm{Fe}$ and 


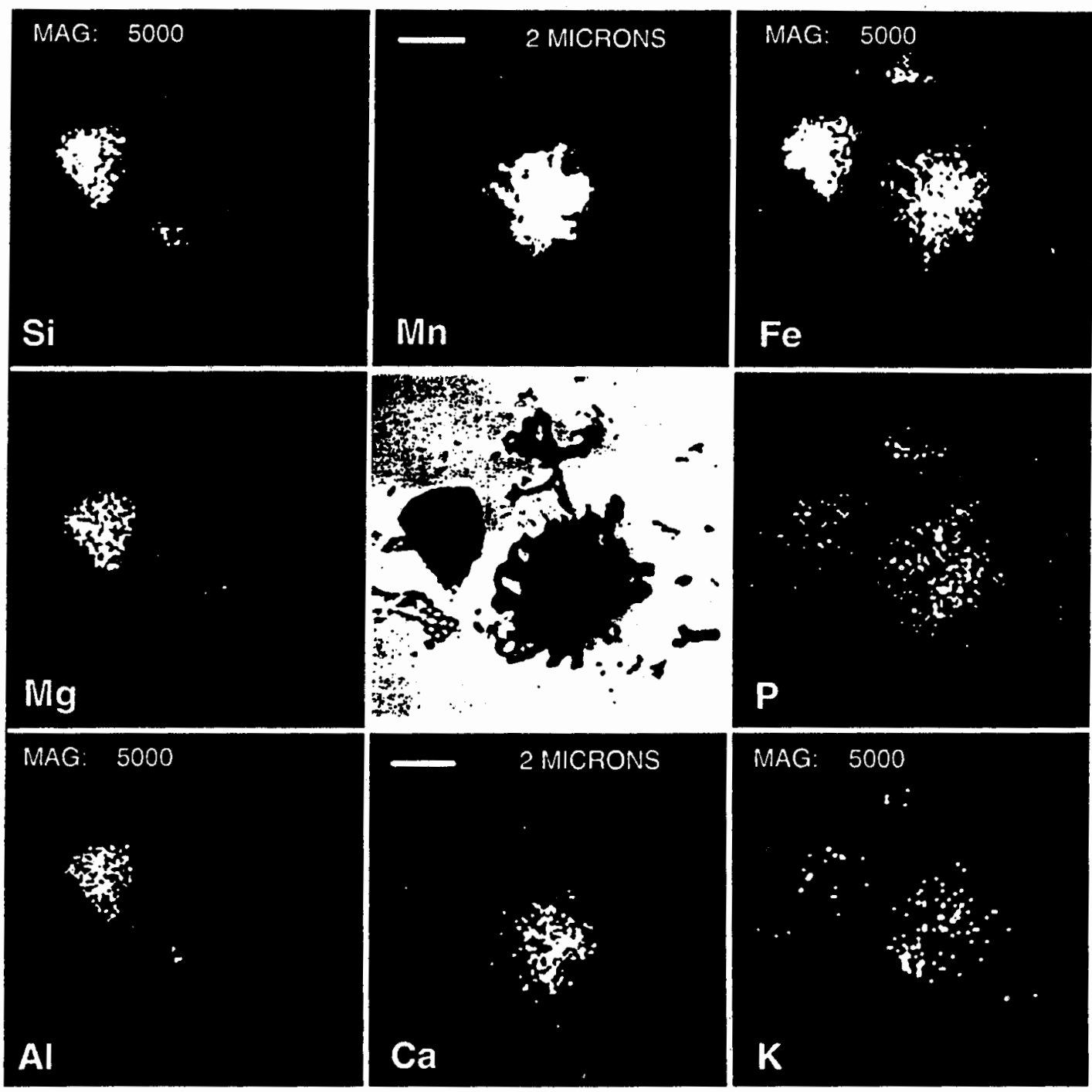

Figure 5. TEM micrograph (central picture) and element scanning of the observation area from trap material $(80 \mathrm{~m})$ colleted in Lake Sempach $(16.09 .1993)$. The Metallogenium-like structure shows high densities of $\mathrm{Mn}$ associated with $\mathrm{Fe}, \mathrm{K}, \mathrm{Ca}$ and $\mathrm{P}$. The structure to the left of the Metallogenium, consists mainly of $\mathrm{Si}, \mathrm{Mg}, \mathrm{Al}$ and $\mathrm{Fe}$ and is identified as biotit

frequently high $\mathrm{Mn}$ densities. However, structures that contained large amounts of $\mathrm{Mn}$ but little iron were poor in $\mathrm{P}$ (Fig. 6). The average Fe:P atomic ratios calculated by means of SEM combined with X-ray analysis was $2.55 \pm 0.87$. Table 5 shows that this ratio was similar to that of the BD extractable Fe-P complexes formed in the hypolimnion. When the samples were treated with $\mathrm{BD}$, the Metallogenium structures disappeared, suggesting that the BD reducible Fe-P complex was part of the Metallogenium structure. 

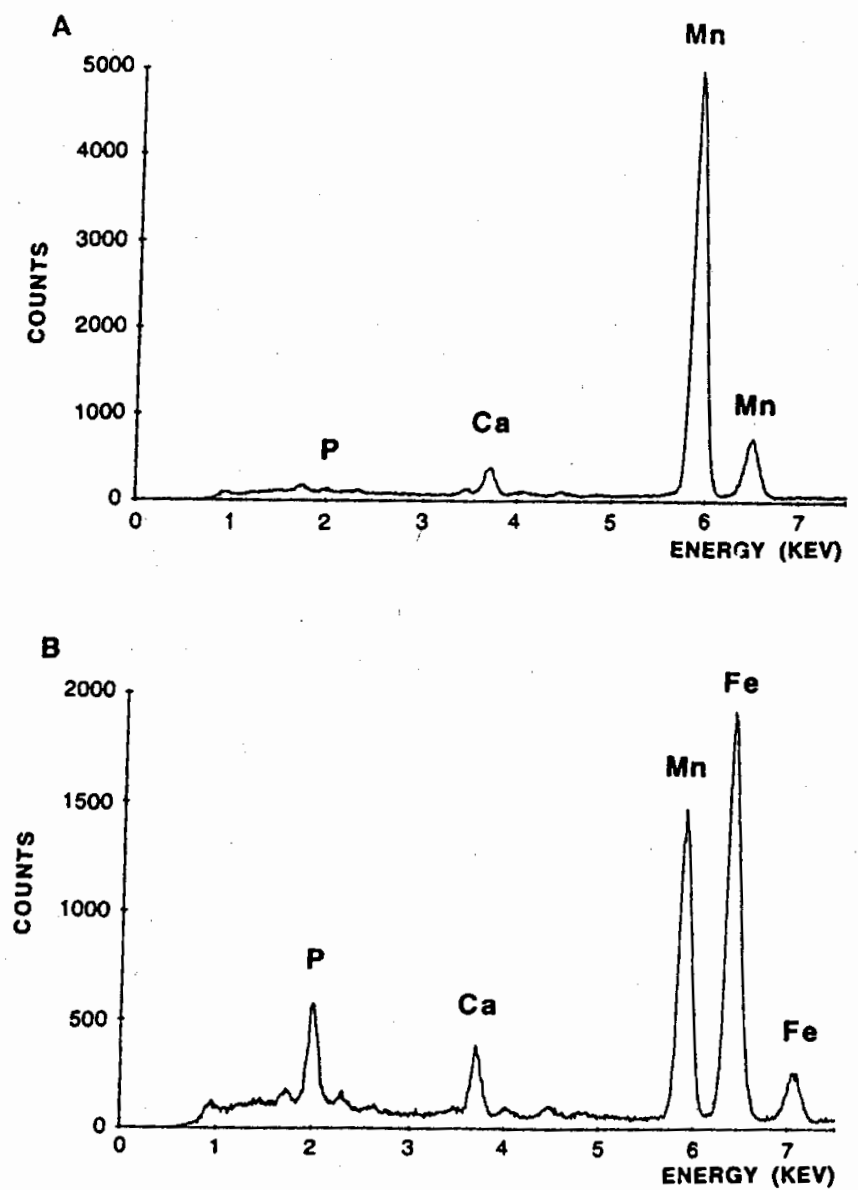

Figure 6. Representative semi-quantitative micro-analysis of Metallogenium-like structurs by $X$-ray spectroscopy. Despite of similar morphological characteristics, the ratios of peak intensities of $\mathrm{Fe}$ and $\mathrm{Mn}$ were highly variable. Examples show Metallogenium-like structures with high (A) and low densities of $\mathrm{Fe}(\mathrm{B})$. Both samples were taken from the $80 \mathrm{~m}$ sediment trap in Lake Sempach

Table 5. Atomic ratios of bicarbonate-dithionite extractable iron (BD-Fe) and phosphorus (BD-TP) of selected trap material collected at $80 \mathrm{~m}$ and the ratio $\triangle B D-F e / \triangle B D-P$, whereas $\triangle B D$ $\mathrm{Fe}$ and $\Delta \mathrm{B} \Delta-\mathrm{P}$ are the concentration differences of samples collected at $80 \mathrm{~m}$ and $20 \mathrm{~m}$. For comparison the atomic $\mathrm{Fe}: \mathrm{P}$ ratios of Metallogenium-like structures analysed by SEM and X-ray spectroscopy (5 replicates of each sample) are shown

\begin{tabular}{llll}
\hline date & $\begin{array}{l}\text { BD-Fe/BD-TP } \\
80 \mathrm{~m}\end{array}$ & $\begin{array}{l}\Delta \mathrm{BD}-\mathrm{Fe} / \Delta \mathrm{BD}-\mathrm{TP} \\
20-80 \mathrm{~m}\end{array}$ & $\begin{array}{l}\text { elemental analysis SEM } \\
\text { Metallogenium }\end{array}$ \\
\hline 28.09 .1992 & 2.48 & 2.33 & 3.62 \\
27.10 .1992 & 2.64 & 1.81 & 2.14 \\
10.11 .1992 & 3.92 & 1.91 & 2.39 \\
02.08 .1993 & 2.23 & 2.71 & 3.64 \\
01.09 .1993 & 1.83 & 1.75 & 1.54 \\
16.09 .1993 & 2.07 & 2.17 & 1.99 \\
Average & $2.53 \pm 0.74$ & $2.11 \pm 0.37$ & $2.55 \pm 0.87$ \\
\hline
\end{tabular}




\section{Early sediment diagenesis}

Figure 7 shows the vertical distribution of $P$ fractions in sediment cores sampled at $20 \mathrm{~m}, 40 \mathrm{~m}$ and $87 \mathrm{~m}$ depths. As a consequence of the formation of an Fe-P complex during sedimentation, BD-TP concentrations were somewhat higher in the surface sediment at $87 \mathrm{~m}$ than at $20 \mathrm{~m}$ and $40 \mathrm{~m}$, respectively. At all sampling depths, the BD-TP was the dominant fraction as the sediment surface. At $87 \mathrm{~m}$ the BD-TP decreased from $1780 \mu \mathrm{g} / \mathrm{g} \mathrm{DW}(61 \%$ of TP) in the uppermost sediment layer to $157 \mu \mathrm{g} / \mathrm{g} \mathrm{DW}$ ( $25 \%$ of TP) $4-5 \mathrm{~cm}$ below the sediment surface. The decrease of BD-P with increasing sediment depth was highly correlated with a decrease of $\mathrm{BD}-\mathrm{Fe}\left([\mathrm{BD}-\mathrm{TP}]=0.374 *[\mathrm{BD}-\mathrm{Fe}]-0.27, r^{2}=0.96, \mathrm{n}=9\right)$, suggesting that during early diagenesis an Fe-P complex with a $\mathrm{Fe}: \mathrm{P}$ ratio of 2.7 was released or transformed into another species. Compared to the distinct changes of BD-TP, other fractions exhibited only small vertical gradients. However, Fig. 7 suggests that after sedimentation, large proportion of the BD-TP, $\mathrm{NaOH}-\mathrm{NRP}$ and $\mathrm{NH}_{4} \mathrm{Cl}-\mathrm{TP}$ are lost during early diagenesis.

At the investigated sampling depths, average $\mathrm{NaOH}-\mathrm{NRP}$ concentrations of the settling material exceeded that of the surface sediment. It is obvious from Figure 8 that most of the $\mathrm{NaOH}-\mathrm{NRP}$ fraction is mobilised immediately after sedimentation, whereas the dissolution of $\mathrm{BD}$-extractable $\mathrm{P}$ occurs during the further diagenesis. No fraction gained $\mathrm{P}$ during diagenesis. Therefore, $\mathrm{BD}-\mathrm{TP}$ and $\mathrm{NaOH}-\mathrm{NRP}$ were definitely lost from the sediment and not transformed into an other solid phase during sediment diagenesis. $\mathrm{HCl}-\mathrm{TP}$ and residual $\mathrm{P}$ concentrations were nearly equal in all samples, indicating that these fractions neither formed nor dissolved in the hypolimnion and in the recent sediment. The net-mobilisation of BD-TP, $\mathrm{NaOH}-\mathrm{NRP}$ and $\mathrm{NH}_{4} \mathrm{Cl}$-TP and the stability of other P-forms during early diagenesis caused a change in the fractional sediment composition. For example, the portion of $\mathrm{HCl}-\mathrm{TP}$ increased from $5 \%$ (80 m trap) to $24 \%(87 \mathrm{~m}, 4-5 \mathrm{~cm}$ sediment depth). Comparisons between the annual $\mathrm{P}$ flux and the $\mathrm{P}$ content of annual sediment layers (calculations according to Gächer and Meyer, 1990) indicated that about $70 \%$ of the settled $P$ was released from the sediment during early diagenesis at sampling depths of $20 \mathrm{~m}$ and $87 \mathrm{~m}$, respectively (Fig. 9).

\section{Discussion}

When Gächter and Mares (1985) observed that settling seston took up instead of releasing $\mathbf{P}$ while settling through the hypolimnion, they speculated that heterotrophic bacteria attached to settling particles took up dissolved SRP from the hypolimnion while decomposing a substrate with a high $\mathrm{C}: \mathrm{P}$ ratio. Results presented in this study are not able to directly test this hypothesis. However, the uptake of SRP did not result in an increase of the $\mathrm{NaOH}-\mathrm{NRP}$ fraction as it would be expected if SRP were converted into organic P or poly-P (Uhlmann et al., 1990; Waara et al., 1993; Hupfer et al., 1995). In stead, most $P$ gained by settling seston in the hypolimnion was inorganic BD-P that was tightly related to a simultaneous formation of a BD-reducible iron oxi-hydroxide. The observation that the BD-soluble Fe-P complex was part of a bacterium of the Metallogenium type offers a new ex- 

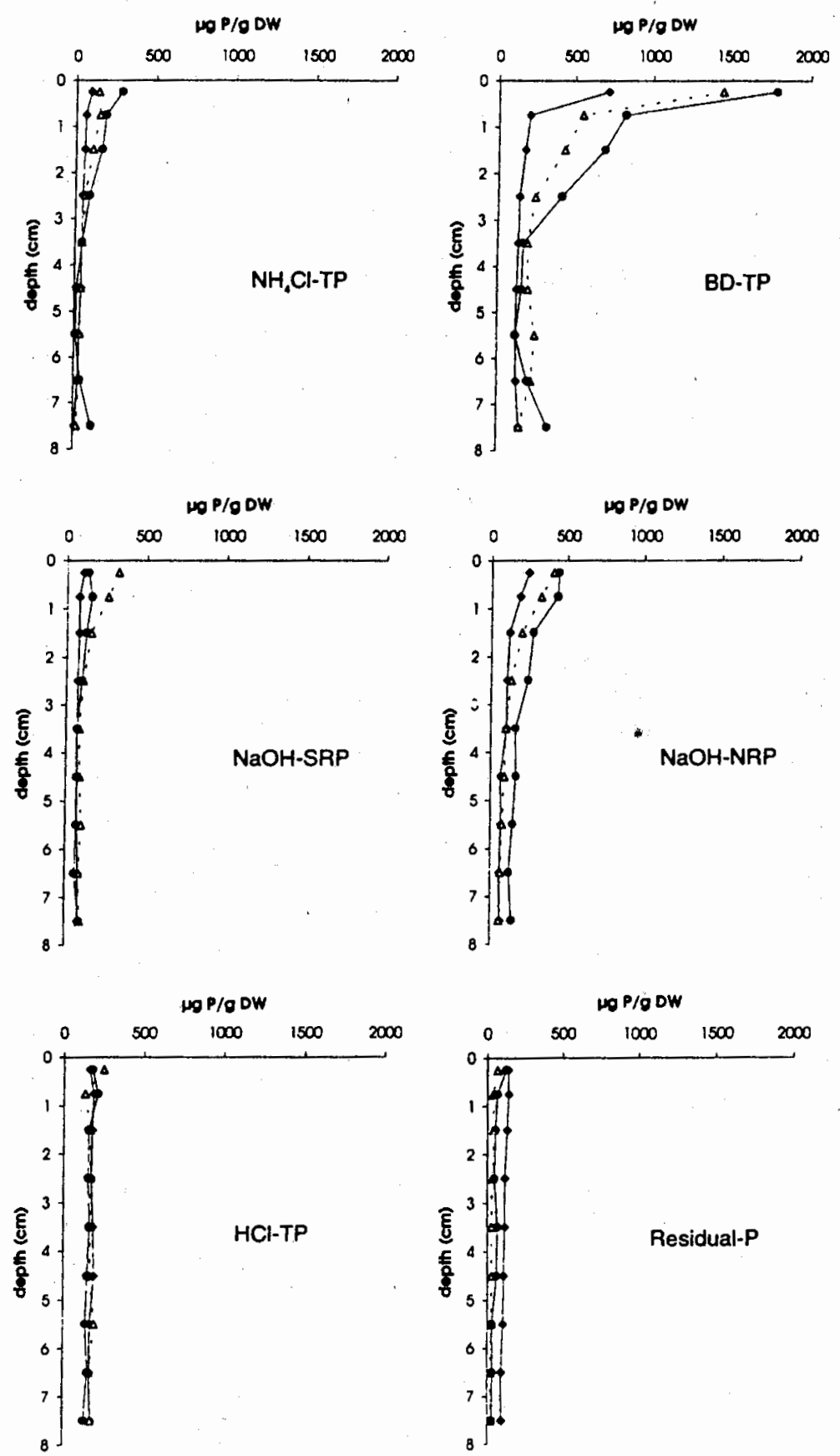

Figure 7. Vertical distribution of various $P$ fractions in sediments of Lake Sempach. The cores were taken at $20 \mathrm{~m}(\rightarrow), 40 \mathrm{~m}\left(--\Delta_{--}\right)$and $87 \mathrm{~m}(--)$ in June and July 1992

Figure 8. Changes in concentrations of total $P$ (horizontal bars) and of various $P$ species (vertical bars) during and after sedimentation in Lake Sempach. Flux weighed average concentrations of trap material are compared with concentrations observed in the two sediment layers 0 to $0.5 \mathrm{~cm}$ and 4 to $5 \mathrm{~cm}$ 


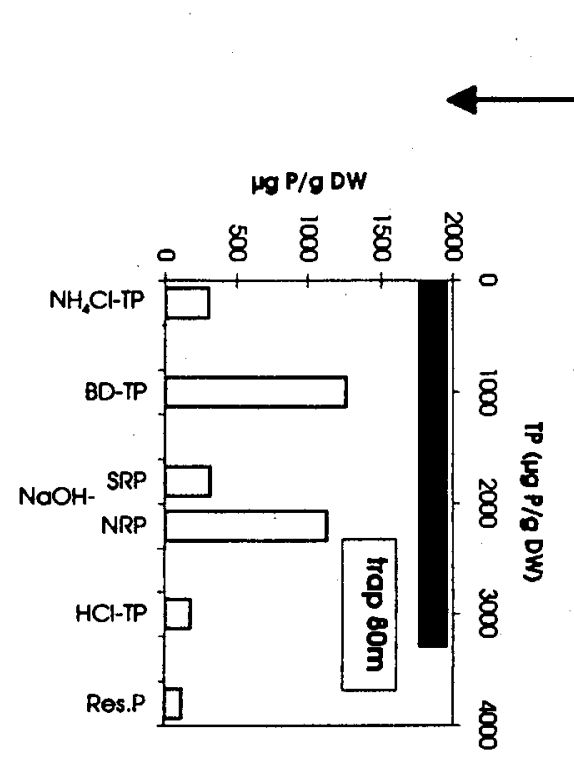

\section{SEDIMENTATION}

ug $P / g$ DW

u P/g DW

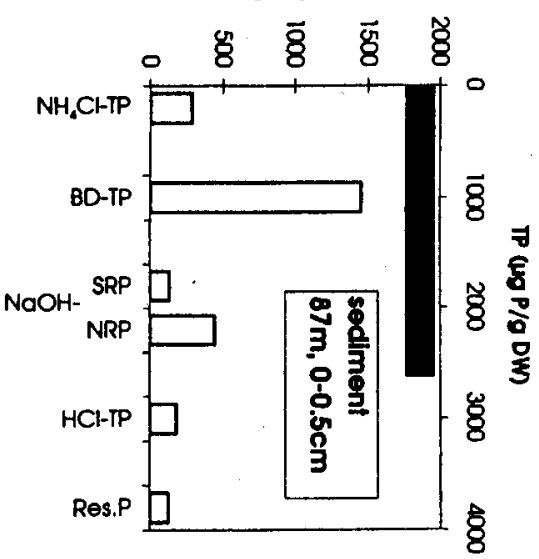

แ $P / g$ DW

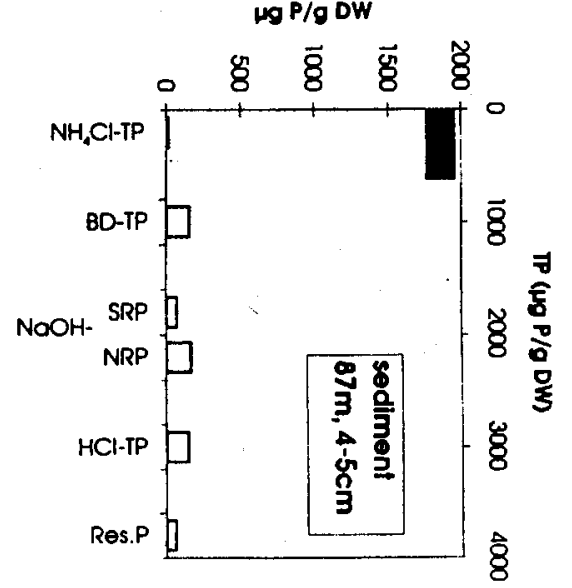

山 $P / g$ DW
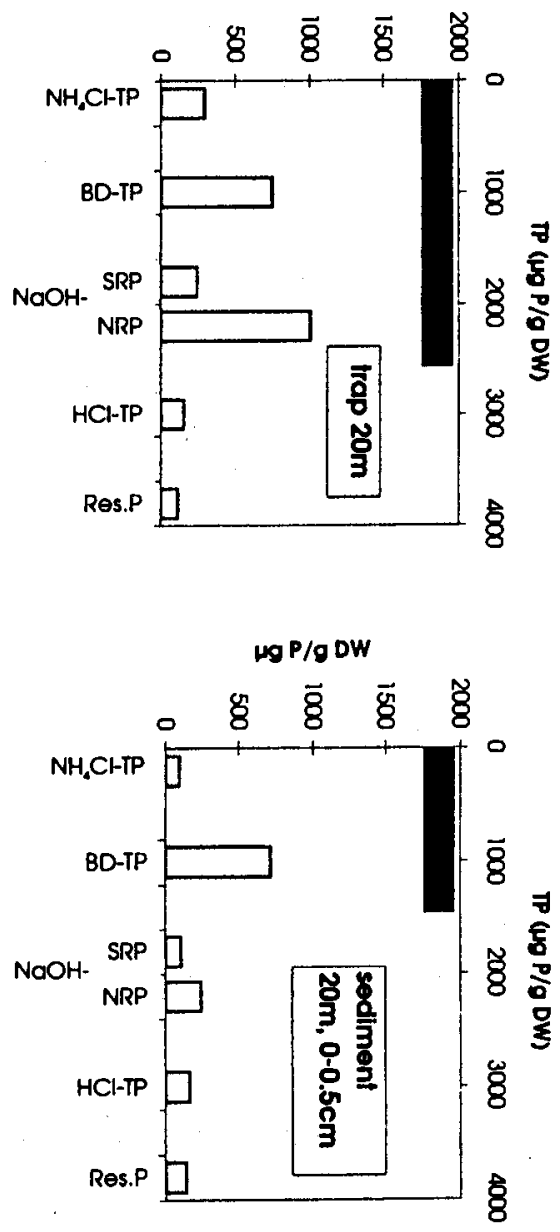

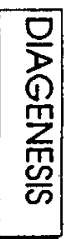

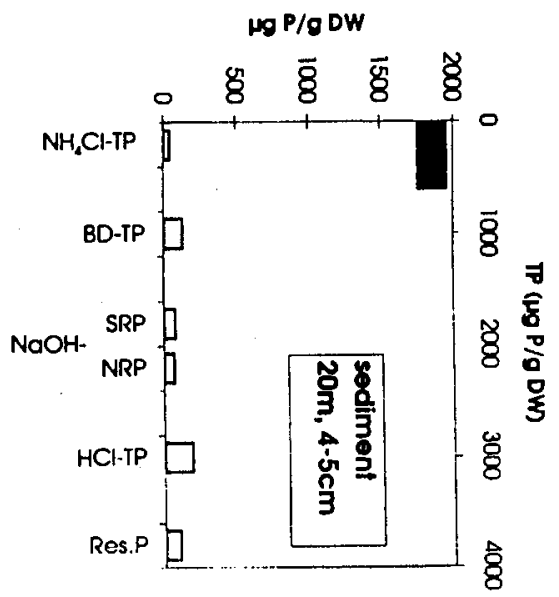




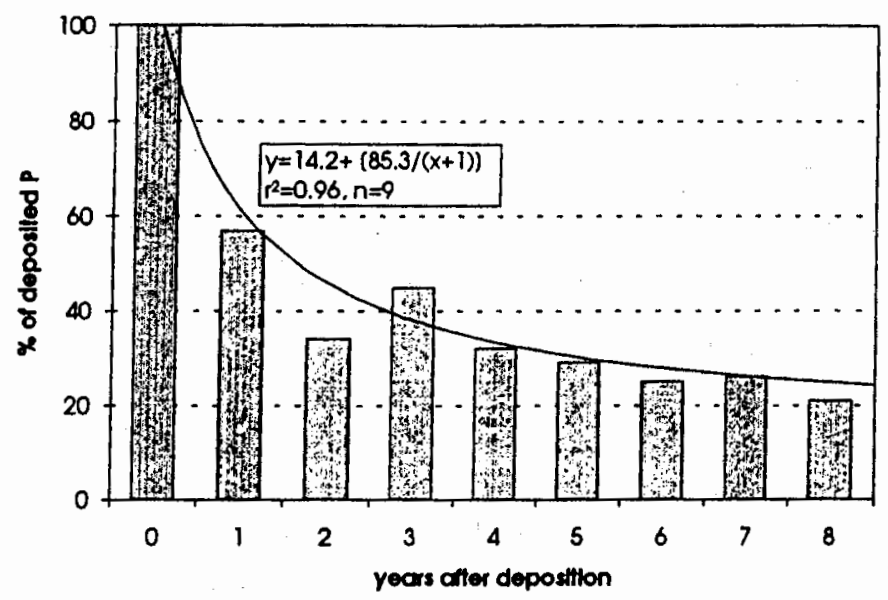

Figure 9. Relative $\mathbf{P}$ content of sediment layers as a function of the elapsed time since deposition. $P$ deposition (gross sedimentation) measured with sediment trap at $80 \mathrm{~m}$ equals $100 \%$. The age of sediment layers was calculated according to Gächter and Meyer (1990)

planation for the observation made by Gächter and Mares (1985): Manganese and iron oxidising bacteria of the type Metallogenium form iron oxihydroxide surfaces that then adsorb SRP "abiotically". Contrary to observations reported by Giovanoli et al. (1980) and Diem (1993), who mainly found $\mathrm{Ca}$ and $\mathrm{Mn}$ in Metallogenium from Lake Zurich, we always observed elevated $\mathrm{P}$ concentrations when elevated $\mathrm{Fe}$ concentrations were observed in these spider-like structures.

Jensen and Thamdrup (1993) observed a strong correlation between BD-P and $\mathrm{BD}-\mathrm{Fe}$ in the sediment of Aarhus Bay. For this sediment they estimated an average atomic Fe:P ratio of 6.3. Zinder (1985) observed ratios of 3 to 4 when iron hydroxide-coated solid surfaces with a thin layer. Our observations based on dissolution experiments with $\mathrm{BD}$ and on results obtained from energy dispersive $\mathrm{X}$-ray spectroscopy suggests that Metallogenium like structures this ratio can even be as low as 2 to 3 .

Petterson and Istanovics (1988) claimed that in sediments rich in calcite BD-P may include part of the $\mathrm{P}$ bound to $\mathrm{Ca}$. However,

- distinct seasonal changes of Ca content in the settling seston had no obvious effects on the BD-TP concentrations (comp. Figures 1 and 2) and the atomic ratio of $\mathrm{BD}-\mathrm{Fe}$ to $\mathrm{BD}-\mathrm{TP}$ (for example the BD-P approached righest values just after calcite sedimentation decreased);

- BD-TP and BD-Fe were strongly correlated (e.g. Figure $4 \mathrm{~b}$ ), but BD-P and the total Ca or BD-Ca were not correlated (not shown); and

- Fe and $P$ are detectable in the same structures (Figures 5 and $6 \mathrm{~b}$ ) with a atomic $\mathrm{Fe}: \mathrm{P}$ ratio similar to those observed in the BD extract (Table 5).

In conclusion, these observations suggest that in Lake Sempach the BD-P was mainly $\mathrm{P}$ adsorbed to $\mathrm{Fe}$.

The increase in P flux observed annually at the end of the turnover period is mainly resulted from a increase of the organic $\mathrm{P}$ flux (NaOH-NRP). In most years between 1988 and 1993, POC and TP fluxes peaked simultaneously in spring before 
the autochthonous calcite precipitation started. The possibility that self-flocculation of $\mathrm{CaCO}_{3}$ and organic particles described by Koschel et al. (1983) may have contributed to the observed increase of organic $\mathrm{P}$ sedimentation cannot be excluded. However, although more than half of the settled material was calcite, the acid soluble $\mathrm{HCl}-\mathrm{P}$, generally attributed to $\mathrm{P}$ associated with calcite, contributed little ( 5 to $7 \%$, Table 3 ) to the total $\mathrm{P}$ sedimentation. Because in the sedimtnt cores, concentrations of this fraction were rather constant (see Figure 7), due to the decreasing concentrations other fractions, the relative importance of the $\mathrm{HCl}$-TP fraction increased with increasing sediment depth up to $24 \%$ at 4 to $5 \mathrm{~cm}$ below the sediment surface. Hence, in Lake Sempach, $\mathrm{P}$ associated with $\mathrm{CaCO}_{3}$ contributed little to $\mathrm{P}$ sedimentation but significantly to the permanent burial of $\mathrm{P}$.

Comparison of the deposition rate measured by sediment traps and the $\mathrm{P}$ content of the corresponding sediment layer indicated that after 5 years of diagenesis, about $70 \%$ of the deposited $P$ was released regardless of the artificially maintained oxic conditions in the hypolimnion since 1985 (Fig. 9). This agrees well with results obtained from whole lake mass balance calculations (Gächter et al., 1989).

If we follow the average concentrations of the various $\mathrm{P}$ fractions from the lower end of epilimnion through the hypolimnion into the sediment (Fig. 8), we observe that with progressing age the concentrations of most fractions decrease or remain unaltered. Since dry weight as a reference may stay constant or decrease but certainly does not increase during diagenesis, observed decreases in concentration (mg P/g DW) must be interpreted as net losses of P. At depths of 20 and $87 \mathrm{~m}$ TP concentrations at the sediment surface were lower than those of the settling particles. This observation suggests that at the sediment surface of Lake Sempach (although the lake is oxygenated) the often postulated trapping of $P$ migrating upward from deeper layers does not occur or, at least, does not result in a net retention of $\mathrm{P}$ by the sediment surface. None of the $P$ fractions showed an increase during sediment diagenesis. The only exception was the BD-TP fraction that transiently increased when particles settled through the hypolimnion. However, when these Fe-P complexes became reduced in the sediment, most of the previously fixed $\mathrm{P}$ was released again. Hence, in eutrophic lakes, the Fe-P complex seems to be only a transient $P$ sink that does not control the ultimate $P$ retention by the sediment, i.e. the net $P$ sedimentation. Although aeration certainly increased $\mathrm{P}$ fixation in the hypolimnion, it did not prevent the post-sedimentary reductive redissolution of the previously formed Fe-P complex. The BD-TP fraction contributed to $41 \%$ to the total $P$ release observed at $87 \mathrm{~m}$ and to $32 \%$ to that observed at $20 \mathrm{~m}$, due to the reductive transformation of the labile Fe-P complex. Although, BD-TP was correlated with BD-Fe in the sediment as it was in the settling particles, the loss of BD-TP did not result in a corresponding loss of total $\mathrm{Fe}$. Although $70 \%$ of the deposited $\mathrm{P}$ was released to the overlying water only $1 \%(20 \mathrm{~m})$ and $12 \%(87 \mathrm{~m})$ of the settled iron was released after sedimentation. This observations suggests that the reduction of the Fe-P complex formed in the hypolimnion resulted in a $\mathrm{P}$-release from the sediment whereas the reduced $\mathrm{Fe}$ to a great extend remained precipitated as $\mathrm{FeCO}_{3}$ or $\mathrm{FeS}$. This results in low $\mathrm{Fe}$ but high $\mathrm{P}$ concentration in the hypolimnion (see also Caraco, 1993), explaining the low Fe: $\mathrm{P}$ rations observed in the newly formed $\mathrm{Fe}-\mathrm{P}$ precipitates.

Gächter et al. (1988) concluded from laboratory and in situ experiments that the rapidly released $\mathrm{P}$ did not only derive from the iron bound $\mathrm{P}$ but also from bacter- 
ial P including poly-P. Boström et al. (1985) interpreted the rapid decrease of residual $\mathrm{P}$ (approximately conform to the $\mathrm{NaOH}-\mathrm{NRP}$ in the Psenner scheme) in sediment of Lake Vallentunasjön by a $\mathrm{P}$ release of micro-organism under anaerobic conditions.

If the $\mathrm{P}$ fractions of the trap material are compared with those of the sediment collected $4-5 \mathrm{~cm}$ below the sediment surface (Fig. 8 ), then it is evident that the losses of BD-TP and NaOH-TP are most important and contribute about equal amounts to the loss of TP during early diagenesis. Figure 8 further indicates that BD-TP concentrations were similar in the trap material and at the sediment surface, whereas the $\mathrm{NaOH}$-TP concentrations were significantly lower at the sediment surface. Hence, after deposition at the lake bottom, the sediment seems to loose $\mathrm{NaOH}-\mathrm{TP}$ more quickly than BD-TP. The NaOH-NRP does not discriminate between detrital and microbial $P$ but it would include microbial poly-P. On three occasions, we observed at a sampling depth of $87 \mathrm{~m} 40-50 \mu \mathrm{g}$ poly-P/g DW in the uppermost sediment layer $(0-0.5 \mathrm{~cm})$, but none in the layer $4-5 \mathrm{~cm}$ below the sediment surface (method see Hupfer et al., 1995). These results confirm former conclusions that the anoxic release of $\mathrm{Fe}$ and $\mathrm{P}$ are partly uncoupled. However on a time scale of years, poly-P hydrolyses seems not to contribute significantly to the release of $P$. Since however poly-P synthesis and hydrolyses have been shown to be quick and reversible reactions, the possibility cannot be excluded that these processes are more important for release and uptake of $P$ over periods of hours to days.

With the applied sequential extraction procedure, transformations of labile $P$ into another solid species resisting dissolution could not be observed either in the hypolimnion or during sediment diagenesis. This does, however, not necessarily mean that such transformations do not occur. Possibly, their detection is just beyond the limits of this analytical method.

In summary we showed in Lake Sempach that

- the P content of settling particles varied seasonally, mainly due to fluctuations of their organic P content (NaOH-NRP);

- settling particles became enriched with inorganic BD-TP while settling through the hypolimnion;

- bacteria oxidising Fe and Mn seemed to be mainly responsible for this increase in $P$ concentration;

- most of the organic P and the iron-bound P (BD-P) were released from the sediment during early diagenesis and

- the sediment surface did not trap P migrating upwards from deeper sediment layers.

\section{ACKNOWLEDGMENTS}

We thank E. Grieder, A. Mares and A. Steffen for their assistance in the field and in chemical analysis. B. Wild and E. Ettinger conducted in electron microscope and X-ray analysis. We also thank B. Boström, J.S. Meyer, R. Psenner, D. Uhlmann, and N. Urban for helpful comments to the manuscript.

This paper is dedicated to Professor Dietrich Uhlmann on the occasion of his 65th birthday. 


\section{REFERENCES}

Boström, B., I. Ahlgren, R. Bell, 1985. Internal loading in a eutrophic lake, reflected in seasonal variations of some sediment parameters. Verh. Int. Verein. Limnol. 22:3335-3339.

Caraco, N. F., J.J. Cole and G. E. Likens, 1993. Sulfate control of phosphorus availability in lakes. Hydrobiologia 253:275-280.

Carignan, R. and R.J. Flett, 1981. Postdepositional mobility of phosphorus in lake sediments. Limnol. Oceanogr. 26, 2:361-366.

Diem, D., 1983. Die Oxydation von Mangan (II) im See. PhD thesis Nr. 7359, Eidgen. Techn. Hochschule, Zürich.

Forsgren, G. and M. Jansson, 1993. Sedimentation of phosphorus in limnetic and estuarine environments in the River Öre system, northern Sweden. Hydrobiologia 253:233-248.

Gächter, R., 1987. Lake restoration. Why oxygenation and artificial mixing cannot substitute for a decrease in external phosphorus load. Schweiz. Z. Hydrol. 49:170-185.

Gächter, R. and T. Mares, 1985. Does settling seston release soluble reactive phosphorus in the hypolimnion of lakes. Limnol. Oceanogr. 30, 2:364-371.

Gächter, R. and J.S. Meyer, 1990. Mechanism controlling fluxes of nutrients across the sediment/water interface in a eutrophic lake. In: Baudo, R., J. Giesy, H. Muntau (eds.): Sediments: Chemistry and Toxicity of In-Place Pollutants, Lewis Publishers, pp. 131-162.

Gächter, R., J.S. Meyer-and A. Mares, 1988. Contribution of bacteria to release and fixation of phosphorusin lake sediments. Limnol. Oceanogr. 33, 6:1542-1558.

Gächter, R., A. Mares, E. Grieder, A. Zwyssig and P. Höhener, 1989. Auswirkungen der Belüftung und Sauerstoffbegasung auf den P-Haushalt des Sempachersees. Wasser, Energie, Luft 81, 11/12:335-341.

Gächter, R., A. Tessier, E. Szabo and R. Carignan, 1992. Measurement of total dissolved phosphorus in small volumes of iron rich interstitial water. Aquatic Sciences 54:1-9.

Giovanoli, R., R. Brütsch, D. Diem, G. Osman-Sigg and L. Sigg, 1980. The composition of settling particles in Lake Zürich. Schweiz. Z. Hydrol. 42, 2:89-100.

Golterman, H. L., 1982. Differential extraction of sediment phosphates with NTA solutions. Hydrobiologia 92:683-687.

Gregory, E., R.S. Perry and J.T. Staley, 1980. Characterisation, distribution, and significance of Metallogenium in lake Washington. Microb. Ecol. 6, 2:125-140.

Hieltjes, A.H.M. and L. Lijklema, 1980. Fractionation of inorganic phosphates in calcareous sediments. J. Environ. Qual. 9.3:405-407.

Hupfer, M., R. Gächter and H. Rüegger, 1995. Polyphosphate in lake sediments: ${ }^{31}$ P NMR spectroscopy as a tool for its identification. Limnol. Oceanogr. 40, 3:610-617.

Jensen, H.S. and B. Thamdrup, 1993. Iron-bound phosphorus in marine sediments as measured by bicarbonate-dithionite extraction. Hydrobiologia 253:47-59.

Jorgensen, S.E., L. Kamp-Nielsen and O.S. Jackobsen, 1975. A submodel for anaerobic mudwater exchange of phosphate. Ecol. Model. 1:133-146.

Kamp-Nielsen, L., 1974. Mud-water exchange of phosphate and other ions in undisturbed sediment cores and factors affecting the exchange rates. Arch. Hydrobiol. 73:218-237.

Kemp, A. L., T.W. Anderson, R. L. Thomas and A. Mudrochova, 1974. Sedimentation rates and recent sediment history of lakes Ontario, Erie and Huron. J. Sediment. Petrol. 44:207-218.

Koschel, R., J. Benndorf, G. Proft and F. Recknagel, 1983. Calcite precipitation as a natural control mechanism of eutrophication. Arch. Hycrobiol. 98:380-408.

Liebezeit, G., 1991. Analytical phosphorus fractionation of sediment trap material. Marine Chem. $33: 61-69$.

Miyajima, T., 1992. Biological manganese oxidation in a lake. 1: Occurrence and distribution of Metallogenium sp. and its kinetic properties. Arch. Hydrobiol. 124. 3:317-335.

Pettersson, K. and V. Istvanovics, 1988. Sediment phosphorus in Lake Balaton - forms and mobility. Arch. Hydrobiol. Beih. 30:25-41.

Psenner, R., R. Pucsko and M. Sager, 1984. Die Fraktionierung organischer und anorganischer Phosphorverbindungen von Sedimenten - Versuch einer Definition ökologisch wichtiger Fraktionen. Arch. Hydrobiol./Suppl. 70, 1:111-155.

Psenner, R., B. Boström, M. Dinka, K. Pettersson. R. Pucsko and M. Sager, 1988. Fractionation of phosphorus in suspended matter and sediment. Arch. Hydrobiol. Beih. 30:98-110. 
Redfield, A. C., B. H. Ketchum and F. A. Richards, 1963. The influence of organisms on the composition of sea water. In: M. H. Hill (ed.), The sea, vol 2. Wiley-Intescience, New York, pp. 26-77.

Ruttenberg, K. C., 1992. Development of a sequential extraction method for different forms of phosphorus in marine sediments. Limnol. Oceanogr. 37:1460-1482.

Stadelmann, P., 1988. Zustand des Sempachersees vor und nach Inbetriebnahne ' :r seeinternen Maßnahmen: Künstlicher Sauerstoffeintrag und Zwangszirkulation 1980-1987. Wasser. Energie, Luft 80:81-96.

Tessenow, U., 1975. Solution, diffusion and sorption in the upper layer of lake sediments. V. The differentiation of the profundal sediments of an oligotrophic mountain lake (Feldsee, Hochschwarzwald) by sediment-water interaction: Arch. Hydrobiol./Suppl. 47, 3:325-412.

Ulén, B., 1978. Seston and sediment in Lake Norvikken III: Nutrient release from sediment. Schweiz. Z. Hydrol. 40:104-305.

Uhlmann, D., I. Röske, M. Hupfer and G. Ohms, 1990. A simple method to distinguish between polyphosphate and other fractions of activated sludge. Wat. Res. $24: 1355-1360$.

Vogler, P., 1965. Beiträge zur Phosphoranalytik in der Limnologie. 2. Die Bestimmung des gelösten Orthophosphates. Fortschr. Wasserchem. Grenzgeb. 2:109-119.

Waara, T., M. Jansson, K. Pettersson, 1993. Phosphorus composition and release in sediment bacteria of the genus Pseudomonas during aerobic and anaerobic conditions. Hydrobiologia 253:131-140.

Williams, J.D., J.K. Syers, D.E. Armstrong and F. Harris, 1971. Fractionation of inorganic phosphate in calcareous lake sediments. Soil Sci. Soc. Amer. Proc. 35:250-255.

Williams, J.D. and T. Mayer, 1972. Effects of sediment diagenesis and regeneration of phosphorus with special reference to Lakes Erie and Ontario. In: H.E. Allen, J.R. Kramer (eds.), Nutrients in natural waters. Wiley-Interscience, pp. $281-315$.

Zinder, B., 1985. Phosphorrücklösung aus Sedimenten als Folge der Reduktion von Eisenoxiden. PhD thesis Nr. 7738, Eidgen. Techn. Hochschule Zürich.

Received 7 November 1994;

revised manuscript accepted 12 April 1995. 